\title{
Relationship Between Maxillary Canine Intra- Alveolar Position and Maxillary Incisor Angulation: A Cone Beam Computed Tomography Study
}

\author{
Carolina BARATIERI \\ Ana Carolina Portes CANONGIA \\ Ana Maria BOLOGNESE
}

UFRJ - Federal University of Rio de Janeiro, Rio de Janeiro, RJ, Brazil

\begin{abstract}
The aims of the present study were to evaluate the angulation and inclination of permanent maxillary incisors and to correlate the results to the intra-alveolar permanent maxillary canine position during mixed dentition, using cone beam computed tomography (CBCT). The subjects were 30 children aged 7 to 10 years in the inter-transitory period of mixed dentition (permanent incisors and first molars erupted; primary canines, first and second molars erupted; and permanent canines intraosseous). The CBCT scans were obtained and, using the Dolphin Imaging ${ }^{\circledR}$ software - version 11.0, 3D images were reconstructed and the measurements were performed. The angulation of the right and left lateral and central maxillary incisors was measured in relation to the sagittal plane and their inclination was measured in relation to the coronal plane. The intra-alveolar height of the right and left maxillary canines was measured from the cusp tip to the axial plane. Pearson's correlation at 5\% significance level showed positive correlation between the canine height and the lateral incisor angulation. It was concluded that the intra-alveolar position of the maxillary canines has a direct influence on the angulation of maxillary incisors, especially the lateral incisors.
\end{abstract}

Key Words: incisors inclination, incisors angulation, mixed dentition, cone beam computed tomography.

\section{INTRODUCTION}

The human dentition development is a continuous complex biological process. Around 6 years old, often with the permanent first molar eruption, the mixed dentition period begins and it is characterized by the replacement of the primary teeth by their permanent successors. The changes are constant and intense until the complete establishment of the permanent dentition. Knowledge of this process enables understanding possible deviations from normal, reducing or eliminating etiologic factors that may not allow further establishment of the ideal occlusion.

For both lay people and dentists, the most significant visible change during the mixed dentition is the position of maxillary incisors (1). While in the primary dentition the incisors are upright, in the early mixed dentition the permanent incisors tend to incline buccally and tip mesially, showing accentuated protrusion and presence of diastema in the anterior region. This characteristic stage of the mixed dentition period was first described by Broadbent as ugly duckling stage (2). It begins at approximately 8 years old and tends to disappear about 12 years of age.

Not only the child's age can range, but also the severity of this stage can vary. The appearance is sometimes very unpleasant and parents/guardians are not aware of this normal stage (3) and might seek orthodontic correction. Around the age of 11, the roots of the lateral incisors are fully formed and the canines erupt about $11 \frac{1}{2}$ years. During eruption, the canine crown moves labially and mesially, uprighting the incisors and closing the diastema (4).

Since its introduction in 1931 (5), cephalometric radiography has been the most important tool for diagnosis and development assessment in Orthodontics. However, measurements are performed in two-dimensional images of three-dimensional (3D) craniofacial structures. The advantages of cone beam computed tomography (CBCT) have turned it into a widely used resource in the dental

Correspondence: Profa. Dra. Ana Maria Bolognese, Departamento de Ortodontia-Odontopediatria, Disciplina de Ortodontia, Avenida Professor Rodolpho Paulo Rocco, 325, Ilha do Fundão, 21941-617 Rio de Janeiro, RJ, Brasil. Tel: +55-21-2590-2727. e-mail: anabolognes@yahoo.com.br 
field (6-9). The increasing technological advance in dental software allows combining cephalometric principles and tools with the advantages of CBCT (10). Measurement errors are reduced because it is possible to visualize the teeth in sagittal, coronal and axial planes without image superimpositions, enabling real dental evaluation $(11,12)$. The application of 3D craniofacial imaging in prospective studies is a major advancement for new, meaningful diagnosis, developmental understanding, and treatment planning, not only in Orthodontics, but also in other areas of Dentistry.

Based on the importance of determining the variations of the position of the maxillary incisors in normal occlusion development (13), the aims of this study were to evaluate the angulation and inclination of central and lateral incisors and to correlate the results to the canine intraosseous position during mixed dentition using CBCT.

\section{MATERIAL AND METHODS}

This study was conducted in the Orthodontics Department of Dental School of the Federal University of Rio de Janeiro, Brazil after approval by the Research Ethics Committee of the Institute for Public Health Research at the same institution (Protocol number 2806.0.000.239-08).

The subjects were 30 children (18 boys and 12 girls) with mean age of 8 years and 7 months in the inter-transitory period of mixed dentition. The inclusion criteria were: age between 7 and 10 years; excellent or good occlusion; no or only mild incisor crowding; erupted permanent incisors and first molars, erupted primary canines, first and second molars, and intraosseous permanent canines; pleasant profile; and no previous orthodontics intervention. After the parents had signed the informed consent form, $\mathrm{CBCT}$ was requested for the children.

All scans were performed in the same CBCT machine (i-CAT, Imaging Sciences International, Hatfield, Hatfield, PA, USA) according to a standard protocol $(120 \mathrm{KVp}, 3-8 \mathrm{~mA}, \mathrm{FOV}=13 \times 17 \mathrm{~cm}$, voxel $=$ $0.4 \mathrm{~mm}$, and scan time $=20 \mathrm{~s}$ ). Results were expressed in DICOM (digital imaging and communication in medicine) format. The Dolphin Imaging software ${ }^{\circledR}$, version 11.0 (Dolphin Imaging, Charsworth, CA, USA) was employed to reconstruct 3D images for further analysis. Using specific software functions, it was possible to standardize the head image position according to axial, coronal, and sagittal planes (14). Axial plane, passing through right and left orbital points as well as right porium; coronal plane, passing through left and right porion, perpendicular to the chosen axial plane; and sagittal plane, passing through nasion point, perpendicular to the chosen axial and coronal planes. After head standardization, it was possible to visualize 3D head image with the reference planes (Fig. 1) and realize the measurements.

The angulation of the right and left central and lateral incisors was measured in relation to the sagittal plane on 3D-reconstruction frontal view. The inclination of the right and left central and lateral incisors was measured in relation to the coronal plane on 3D-reconstruction lateral view. The height of the intraosseous right and left canines was measured on $45^{\circ}$ lateral view in relation to the axial plane (Figs. 2 and 3).

Prior to the measurements, aiming to determine the reproducibility of the present study, 10 scans were randomly selected and the measurements were taken under the same conditions at two moments within a 2 -week interval. Intraclass correlation test was applied in order to verify the intra-examiner concordance $(95 \%$ confidence interval). Agreement greater than 0.91 was obtained for all variables analyzed.

Means, standard deviations, variance, minimum and maximum values were calculated for each variable: right central incisor angulation, left central incisor angulation, right lateral incisor angulation, left lateral incisor angulation, right central incisor inclination, left central incisor inclination, right lateral incisor inclination, left lateral incisor inclination, right canine height and left canine height). After normal data distribution was confirmed by the Kolmogorov-Smirnov non-parametric test, the correlation and statistical significance $(\mathrm{p}<0.05)$ between incisor inclination/angulation and canine height were identified using Pearson's correlation test. Statistical analysis was performed using SPSS software version 16.0 (SPSS Inc., Chicago, IL, USA).

\section{RESULTS}

Results of the descriptive analysis and Pearson's correlation are shown in Table 1 and 2, respectively.

\section{DISCUSSION}

In addition to the normal changes occurred during the development of dentition, there is also large 


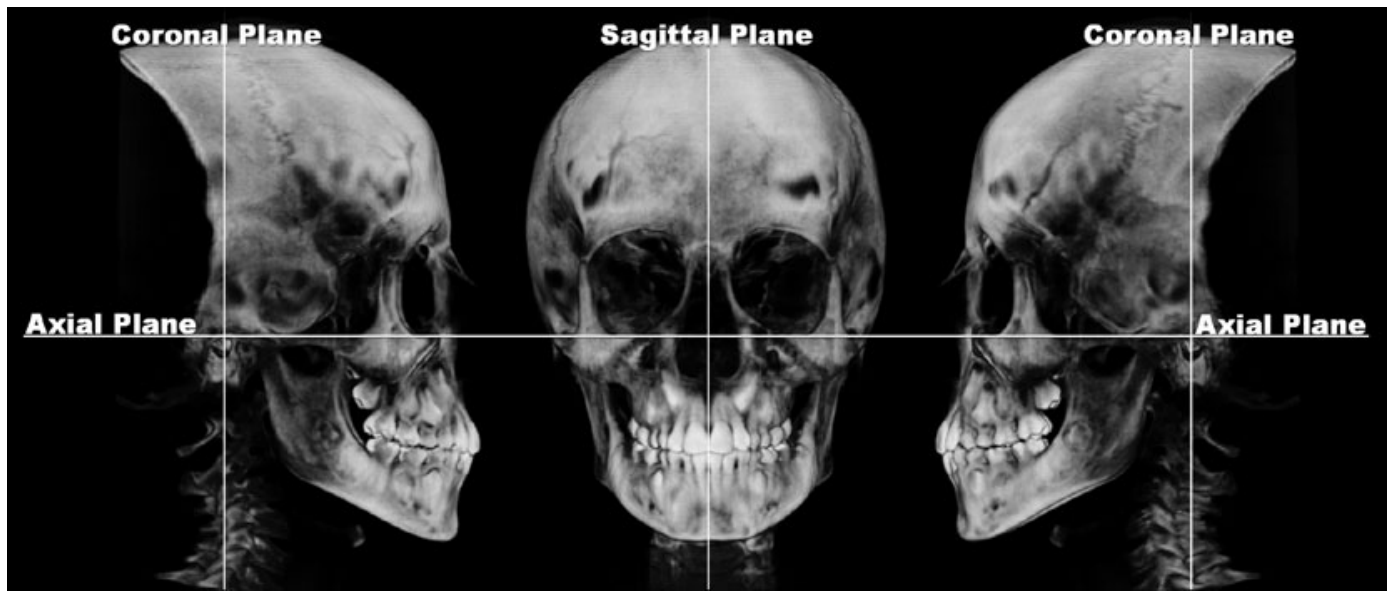

Figure 1.3D digital head image after orientation by axial, coronal and sagittal planes (Software Dolphin Imaging ${ }^{\mathbb{B}} /$ Orientation function).
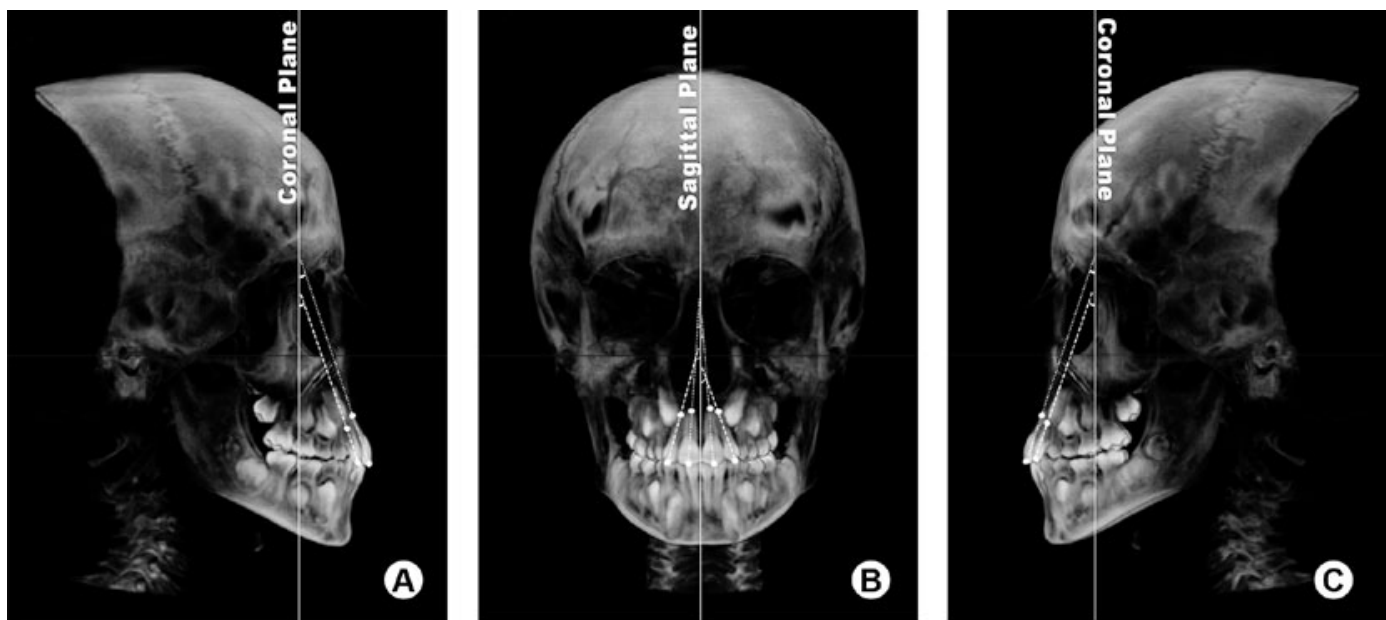

Figure 2. Angular measurements on 3D image view. $\mathrm{A}=$ Right lateral view with right central and lateral incisor inclination; $\mathrm{B}=$ Frontal view with right and left central and lateral incisor angulation; $\mathrm{C}=$ Left lateral view with left central and lateral incisor inclination (Software Dolphin Imaging ${ }^{\circledR} /$ Measurement function).
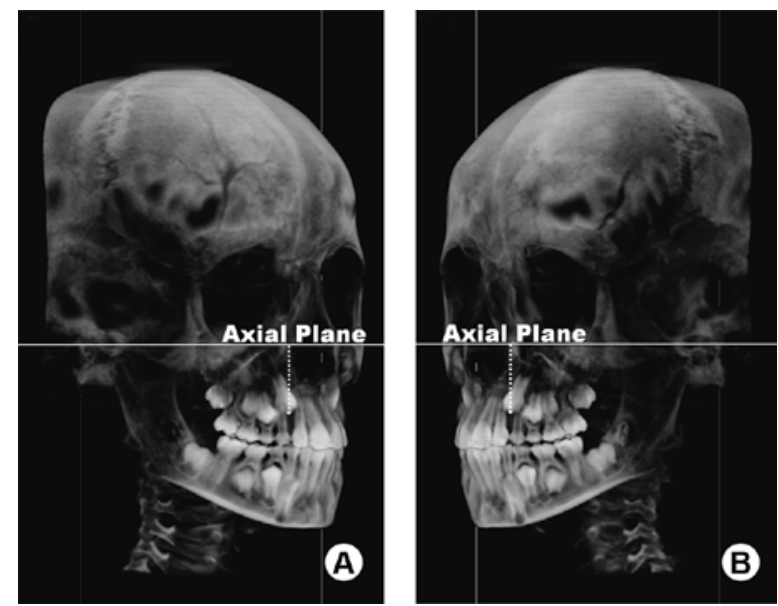

Figure 3. Linear measurements of upper canine intra-alveolar position on 3D image view. A= Right $45^{\circ}$ lateral view with the distance of right canine tip cuspid to axial plane; $\mathrm{B}=\mathrm{Left} 45^{\circ}$ lateral view with the distance of left canine tip cuspid to axial plane (Software Dolphin Imaging $\mathbb{\circledR} /$ Measurement function). 
individual variation of the dental characteristics in this period (15). As observed in the present study, even in children with normal development of mixed dentition, the inclination and angulation of the maxillary incisors as well as the intraosseous position of the maxillary canine showed great variability among these children (Table 1). The largest variation was found in the lateral incisor angulation $\left(60.69^{\circ}\right.$ and $46.27^{\circ}$ for the left and right incisors, respectively). However, when the features were compared into the same child, the results of the

Table 1. Descriptive analysis of all variables' measurements $(n=30)$.

\begin{tabular}{|c|c|c|c|c|c|}
\hline & Min. & Max. & Mean & SD & Variance \\
\hline rCI angulation $\left({ }^{\circ}\right)$ & -3.2 & 17.6 & 3.08 & 4.0 & 16.26 \\
\hline 1CI angulation $\left(^{\circ}\right)$ & -1.5 & 11 & 5.08 & 3.1 & 10.05 \\
\hline rLI angulation $\left(^{\circ}\right)$ & -7.5 & 27.9 & 16.75 & 7.7 & 60.69 \\
\hline ILI angulation $\left({ }^{\circ}\right)$ & 5.1 & 31.6 & 17.32 & 6.8 & 46.27 \\
\hline rCI inclination $\left(^{\circ}\right)$ & 11.5 & 36 & 22.59 & 6.1 & 37.28 \\
\hline 1CI inclination $\left({ }^{\circ}\right)$ & 12.5 & 35.9 & 24.33 & 5.5 & 30.55 \\
\hline rLI inclination $\left({ }^{\circ}\right)$ & 13.2 & 34.5 & 21.55 & 5.8 & 34.42 \\
\hline ILI inclination $\left({ }^{\circ}\right)$ & 11.5 & 30 & 21.48 & 5.1 & 26.08 \\
\hline rC height (mm) & 18.9 & 32 & 27.47 & 3.1 & 9.61 \\
\hline 1C height (mm) & 18.4 & 33.6 & 27.53 & 3.5 & 12.44 \\
\hline
\end{tabular}

$\mathrm{n}=$ sample number; $\mathrm{Min}=$ minimum; $\mathrm{Max}=$ maximum; $\mathrm{SD}=$ standard deviation. $\mathrm{rCI}=$ right central incisor; $1 \mathrm{CI}=$ left central incisor; $\mathrm{rLI}=$ right lateral incisor; $1 \mathrm{LI}=$ left lateral incisor.

Table 2. Results of Pearson's correlation between the angulation and inclination of the maxillary incisors and the height of intraosseous maxillary canines.

\begin{tabular}{|c|c|c|c|c|c|}
\hline & \multicolumn{2}{|c|}{ Right Canine } & & \multicolumn{2}{|c|}{ Left Canine } \\
\hline & Correlation & $\mathrm{p}$ valor & & Correlation & $\mathrm{p}$ valor \\
\hline $\begin{array}{c}\mathrm{rCI} \\
\text { angulation }\end{array}$ & .460 & $.011 *$ & $\begin{array}{c}1 \mathrm{CI} \\
\text { angulation }\end{array}$ & -.088 & .642 \\
\hline $\begin{array}{c}\text { rLI } \\
\text { angulation }\end{array}$ & .583 & $.001 * *$ & $\begin{array}{c}1 \mathrm{LI} \\
\text { angulation }\end{array}$ & .527 & $.003 * *$ \\
\hline $\begin{array}{c}\mathrm{rCI} \\
\text { inclination }\end{array}$ & -.192 & .309 & $\begin{array}{c}1 \mathrm{CI} \\
\text { inclination }\end{array}$ & -.141 & .456 \\
\hline $\begin{array}{c}\text { rLI } \\
\text { inclination }\end{array}$ & -.336 & .069 & $\begin{array}{c}\text { ILI } \\
\text { inclination }\end{array}$ & -.183 & .332 \\
\hline
\end{tabular}

Level of significance $=* \mathrm{p}<0.05 ; * * \mathrm{p}<0.01 ; \mathrm{rCI}=$ right central incisor; $1 \mathrm{CI}=$ left central incisor; $\mathrm{rLI}=$ right lateral incisor; $1 \mathrm{LI}=$ left lateral incisor. right and left side were similar, showing small intraindividual variability.

The canine intraosseous position is reported as one of the responsible for the tipping of permanent incisors due to the proximity of their bulky crown with the incisors' root $(16,17)$. In the present study, the canine position had greater influence on the angulation rather than on the inclination of the incisors, as shown by statistically significant, though weak, correlation. The lateral incisor was more influenced than the central incisor (Table 2). Hence, the more occlusal the permanent maxillary canine crown, the lower the lateral incisor angulation. This fact agrees with the results of Broadbent (2), who described that the appearance of incisors during this mixed dentition stage is directly influenced by the canine position and it is self-corrected by its eruption.

No correlation was found between canine height and incisor inclination (Table 2). This fact is in agreement with the results of a previous study (18) that reported self-correction of excessive incisor protrusion in this period, much more due to the perioral musculature than to canine eruption.

Providing imaging in 3 dimensions has demonstrated a profound effect on medical and dental practice since its introduction. CBCT systems have been developed specifically for the maxillofacial region and have been frequently applied to orthodontic assessment. In addition to producing lower doses and having lower costs when compared to medical fan beam CT, orthodontic diagnosis using 3D $\mathrm{CT}$ has recently been brought into attention for the following reasons: actual measurement without distortion regardless of head posture (14); real, not projected, 
landmarks, are used for the dimensional measurements $(11,12,19)$; and possibility of volumetric measurements (20). Hence, CBCT images facilitate the diagnosis and guidance throughout the treatment phase.

The mixed dentition phase is recognized as the best time to intercept problems that interfere with the growth and the development of the dento-maxillary complex. Any orthodontic intervention during this period must consider the intimate relationship of the permanent maxillary canine intraosseous position and the root of the permanent maxillary lateral incisor. Despite the great variability found in the incisor angulation and inclination of the children, the canine intraosseous position had great impact on the angulation of the incisors.

\section{RESUMO}

Os objetivos deste estudo foram avaliar, por meio de tomografia computadorizada de feixe cônico (TCFC), a inclinação mésiodistal e vestíbulo-lingual dos incisivos permanente superiores e correlacionar os resultados com o posicionamento intra-ósseo do canino permanente superior na dentição mista. Foram selecionadas 30 crianças, entre 7 e 10 anos de idade, no período inicial de dentição mista, apresentando incisivos e primeiros molares permanentes erupcionados, caninos, primeiros e segundos molares decíduos presentes na cavidade bucal e caninos permanentes intra-ósseos. Foi realizada TCFC e com o software Dolphin Imaging ${ }^{\circledR}$, versão 11.0 foi realizada a reconstrução em 3D destas imagens e feitas as medidas. A inclinação dos incisivos centrais e laterais superiores direito e esquerdo foi medida em relação ao plano sagital (angulação mésio-distal) e ao plano coronal (inclinação vestíbulo-lingual). A altura intra-óssea dos caninos superiores direito e esquerdo foi medida da ponta da cúspide ao plano axial. Para análise da correlação entre a angulação dos incisivos e altura dos caninos foi utilizado o teste de correlação de Pearson, ao nível de significância de 5\%. Pode-se concluir que a posição intra-óssea dos caninos superiores sugere influência direta na inclinação dos incisivos superiores, principalmente nos incisivos laterais.

\section{REFERENCES}

1. Schaeffer A. Behavior of the axis of human incisor teeth during growth. Angle Orthod 1949;19:254-275.

2. Broadbent BH. Ontogenic development of occlusion. Angle Orthod 1941;11:223-241.

3. Lewis $\mathrm{AB}$. The relationship between tooth formation and other maturational factor. Am J Orthod 1960;30:70-77.

4. Coenraz FA. Availble space for the incisoros during dental development. Am J Orthod 1965;35:12-22.
5. Broadbent BH. A new x-ray technique and its application to orthodontics. Angle Orthod 1931;1:45-66.

6. Oliveira CAP, Meurer MI, Pascoalato C, Silva SRC. Cone-beam computed tomography analysis of the apical third of curved roots after mechanical preparation with different automated systems. Braz Dent J 2009;20:376-381.

7. Alves MJ, Baratieri C, Nojima LI. Assessment of mini-implant displacement using cone beam computed tomography. Clin Oral Impl Res 2011 [DOI: 10.1111/J1600-0501.2010.02092.x. - Epub ahead of print].

8. Baratieri C, Nojima LI, Jr MA, Souza MMGd, Nojima MG. Transverse effects of rapid maxillary expansion in Class II malocclusion patients: a cone-beam computed tomography study. Dental Press J Orthod 2011;15:89-97.

9. Silva MAG, Wolf U, Heinicke F, Bumann A, Visser H, Hirsh E. Cone-beam computed tomography for routine orthodontic treatment planning: a radiation dose evaluation. Am J Orthod Dentofacial Orthop 2008;133.

10. Moshiri M, Scarfe WC, Hilgers ML, Scheetz JP, Silveira AM, Farman AG. Accuracy of linear measurements from imaging plate and lateral cephalometric images derived from conebeam computed tomography. Am J Orthod Dentofacial Orthop 2007;132:550-560.

11. Ludlow JB, Gubler M, Cevidanes L, Mol A. Precision of cephalometric landmark identification: Cone-beam computed tomography vs conventional cephalometric views. Am J Orthod Dentofacial Orthop 2009;136:312.e1-12.e10.

12. de Oliveira AEF, Cevidanes LHS, Phillips C, Motta A, Burke B, Tyndall D. Observer reliability of three-dimensional cephalometric landmark identification on cone-beam computerized tomography. Oral Surg Med Pathol Radiol Endod 2009;107:256-265.

13. Oltramari PVP, Conti ACDCF, Navarro RDL, Almeida MRD, Almeida-Pedrin RRD, Ferreira FPC. Importance of occlusion aspects in the completion of orthodontic treatment. Braz Dent $\mathrm{J}$ 2007; 18:77-82.

14. Cevidanes L, Oliveira AEF, Motta A, Phillips C, Burke B, Tyndall D. Head Orientation in CBCT-generated Cephalograms. Angle Orthod 2009;79:971-977.

15. Moyers RE. Analysis of the dentition and occlusion. In: Handbook of Orthodontics. Moyers RE (Editor). 4th ed. Chicago: Year Book Medical Publishers; 1988. p. 235-238.

16. Ericsson S. Resorption of maxillary lateral incisors caused by ectopic eruption of the canines. Am J Orthod Dentofacial Orthop 1988;94:503-513.

17. Hellhart WC. Case report: management of significant incisor root resorption associated with maxillary canine impaction. Angle Orthod 1998;68:187-192.

18. Posen AL. The influence of maximum perioral and tongue force on the incisor teeth. Angle Orthod 1972;42:285-309.

19. Brown AA, Scarfe WC, Scheetz JP, Silveira AM, Farman AG. Linear accuracy of cone beam CT derived 3D images. Angle Orthod 2009;79:150-157.

20. Zhao Y, Nguyen M, Gohl E, Mah JK, Sameshima G, Enciso R. Oropharyngeal airway changes after rapid palatal expansion evaluated with cone-beam computed tomography. Am J Orthod Dentofacial Orthop 2010;137:S71-S78. 